\title{
Oil \& Gas Industry of Kurdistan Region of Iraq: Challenges and Opportunities
}

\author{
Ibtisam Kamal* \\ Petroleum Geosciences department, Soran University, Kurdistan region-Iraq \\ *Corresponding author: Ibtisam Kamal, Petroleum Geosciences department, Soran University, Kurdistan region-Iraq.
}

Submission: 望 June 22, 2018; Published: 眥July 02, 2018

\begin{abstract}
Kurdistan region of Iraq became one of the active areas for onshore oil and gas exploration in recent years.In spite of the continuing progress made in exploration, drilling, completion and production combined with the improving infrastructure which is expected to allow Kurdistan Region of Iraq to be a significant factor in the oil world there is some challenges face this progress. The article gives an overview of the oil and gas reserves production capacity and cost of oil and gas, in addition to highlighting the challenges to oil sector and the guides to improving the management of oil and gas industry in Kurdistan region.
\end{abstract}

Keywords: Kurdistan region of Iraq; Oil and gas industry; Challenges; Management

\section{Overview}

Although, Kurdistan region of Iraq has significant potential for metallic and non-metallic minerals, the region all attention focused on the hydrocarbon sector leaving the former resources mostly undeveloped hence, the entire economy of Kurdistan region-Iraq became almost based on its oil and gas reserves. Oil and gas development in Kurdistan region of Iraq has become an important and contentious issue since 2005. The region has been one of the active areas for onshore oil and gas exploration in recent years. Kurdistan region of Iraq has enjoyed relative peace for a number of years whilst much of Iraq may be viewed as in a meta-stable social and political state. This has enabled the regional government to develop oil exploitation laws and to lease much of the land to foreign exploration and production companies. According to OPEC, Kurdistan region of Iraq accounts for 43.7 billion barrels of proven oil reserves 25.5 billion more barrels of unproven reserves and between 3 and 6 trillion cubic meters of gas accounting for (30\% of Iraq's proven oil reserves and $89 \%$ of all gas reserves of Iraq) [1]. These figures would put Kurdistan region among the top 10 oil rich regions in the world (in the 8th place in the world for oil and gas reserves).

According to Ministry of Natural Resources (MNR), the production of oil in Kurdistan region is expected to grow to reach 2 million barrels per day (bpd) by 2035 (Figure 1). However, the KRG has established an ambitious program to increase production capacity to achieve the same capacity by 2019 [2]. Kurdistan oil production forecast for the top five companies is illustrated in Figure 2. On another hand, gas production stood at around 3-4 (Billion cubic meters) annually up to 2015 , the forecast revealed that gas produc tion will grow afterward every year it will be five times by 2035 as shown in Figure 3. Gas production is currently entirely for domestic use for local power generation. However, KRG planned to extend a pipeline to transport natural gas from gas fields in Kirkuk to Turkey. (KRG) is expected to flow the gas into Turkey within the next two years then reach the European market in early 2020 [3]. In addition to developments in exploration, the region is also expanding its refining capabilities with two major facilities already in place owned and operated by the private sector. Kalak refinery near Erbil city operated by Kar Group and Bazian refinery in Sulaymania governorate operated by WZA Petroleum.

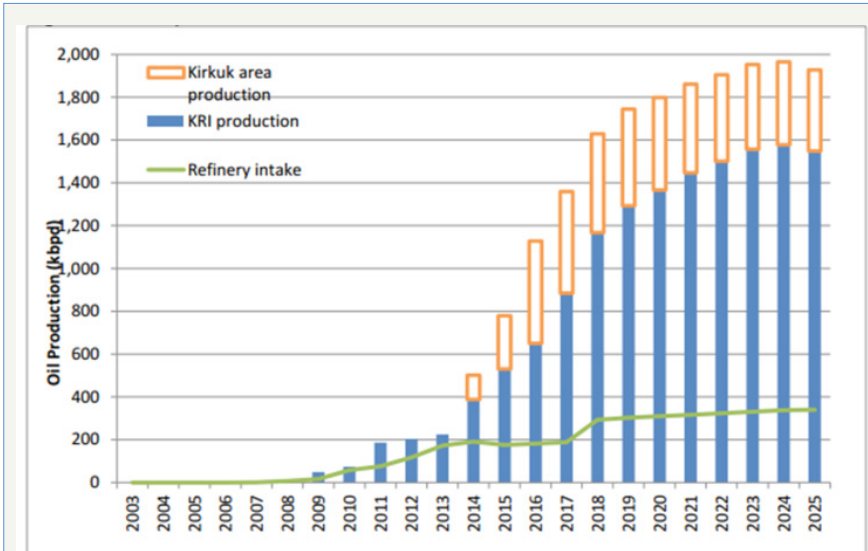

Figure 1: Kurdistan oil production forecast up to 2035. Source: MN Rreports; Wood Mackenzie; author's estimates [2]. 


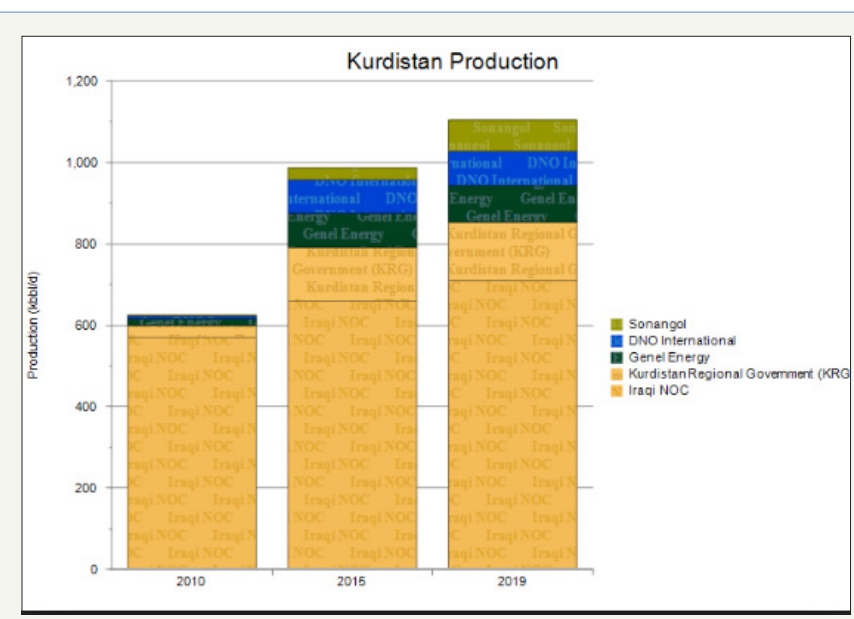

Figure 2: Kurdistan oil production forecast for the top five companies. Source: Rystad Energy UCUBE.

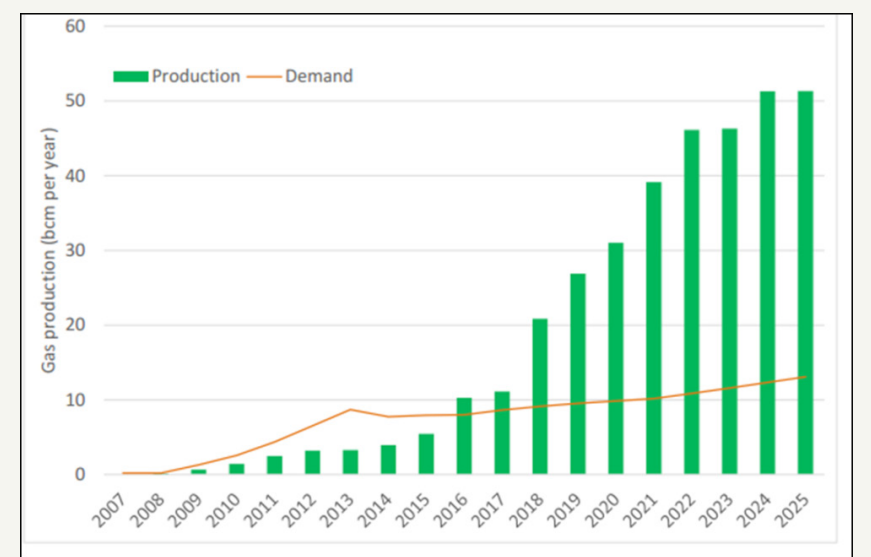

Figure 3: Kurdistan gas production and demand. Source: MNR reports; Wood Mackenzie; author's calculations [2].

KRG has awarded licenses to a broad spread of companies more than fifty International Oil Companies (IOCs) are involved in the region. Super majors with Western firms (at first mostly the USA, Canada and the UK) and Turkey because of its regional importance. Turkish companies including Genel Energy in the early days and some smaller private Turkish players. Later on more continental European companies have become involved with critically important entities including from France (Total), Spain (Repsol), Hungary (MOL), Austria (OMV), and Denmark (Maersk). Of non-Western firms, Sinopec, via Addax (China), Gazprom Neft (Russia) and TAQA, Crescent and Dana Gas (UAE) are notable [4]. The qualified companies split into operating companies and non-operating companies that can compete on contracts but only as a partner in a combine that is le by an operating company.

In an attempt to bridge the gap between uneven domestic fuels supplies and rising demand, Kurdistan Regional Government (KRG) has planned to attract private bids for three new refineries with a total of 1,50,000 barrels per day (bpd) of capacity [5]. With the export of 2 to 4 million barrels of oil per day within the next decade and with a population of 4 million, Kurdistan region-Iraq could expect to become wealthy like Norway and the Gulf emirates [6].

\section{Crude Oil Production Cost \& Price}

Generally, the total cost of producing crude oil includes all of the costs from project site plan development to lifting oil from the well. The total cost of producing crude oil is broken into two categories: Capital Expenditure and Operational Expenditure. Capital expenditure is the total costs associated to the operations of exploration and drilling, processing and construction of facilities and pipelines and equipment, while operational expenditure includes the total costs related to the operations of the pumping of oil from the fields and the maintenance and the salaries of the workforce, experts and transportation of oil. The cost of oil production is affected by several factors including:

\section{A. The geographical nature}

Geographical nature is the most important element that have influence on the cost of oil production huge wild fields have low production cost, while the cost of production in the offshore of the shallow water is more and cost of fields in deep water are very high.

\section{B. The extraction cost}

The extraction cost increases wherever the extraction is extended to the stocks or reserves which are less quality or purity.

\section{The political and security challenges}

The political and security challenges increase investment costs, so production cost increases. On another hand oil prices usually fluctuated based on different variables. The variables include:

a. Supply and demand: If production is more than demand, prices will fall and if there is a shortage of oil, prices will rise.

b. Political events: A war, rebellion or political uncertainty affecting major oil producers may prevent those countries from producing and selling, reducing the supply of oil.

c. Economic growth: If demand is expected to grow faster than production, excess supply will be soaked up and shortages will arise.

d. Related markets: The futures market, availability of transport, currency rates and the cost and of extraction equipment and labor can all affect the price of oil.

e. Weaker Dollar: The market price of crude oil is valued in US dollars. So weaker dollar will raise oil price. Increasing the strength on Dollar making oil more expensive to buy.

f. Oil inventories and storage space: Storage space shortage could cause a drop in prices. Oil that can't be moved to where it needs to go quickly drops in price.

g. Disruption in supplies: Disruption in oil supply as a result of terrorism, strikes, sabotage or lack of maintenance is all 
sharp reasons for price fluctuations. Putting out oil production and oil platform offline for maintenance will increase oil prices.

h. Slowing down of economic growth in Eurozone countries.

i. Increasing Shale oil production in US/US import of oil from OPEC reduced.

j. OPEC countries trials to lower prices to maintain their market share.

Finally, there is no single or easy answer to the question of what will the future price of crude oil is? What drive oil prices are global oil consumption, economic growth patterns, technological innovation, and political dynamics in oil producing countries [7].

\section{Challenges to Oil Sector}

In spite of the continuing progress made in exploration and production combined with improved infrastructure which is expected to go a long way towards allowing Kurdistan Region of Iraq to establish itself as a significant factor on the world stage, there is some challenging faced this progress:

A. Insecurity and instability continued to impede the development of oil sector. For example, ISIS attacking near Kurdistan boarders created negative image for investment climate in the energy sector and other sectors as well. Oil companies had shared concern about the security of investment in such circumstances.

B. The increasing complexity of remote and extreme operational environments for exploration oil in remote areas like mountains. Difficulties rise in petroleum products storage and handling terminals.

C. Project delays and inhibiting long-term production targets owing to hanging the law of Oil and gas since 2008 in the Iraqi parliament.

\section{Improving the management of oil and gas industry}

An effective and efficient management system of oil and gas industry is a precondition for the success of government budget allocation. An assistance of international development partners will be better suited for revenue-sharing among provinces to ensure fair and efficient allocation. From the author point of view, improving the management of oil and gas industry in Kurdistan region of Iraq could be conducted throughout the following concluding thoughts:

A. The International oil companies have more experience in negotiating contracts based on a clear, single objective which is maximizing revenues and internal rates of return; they also have the financial capability to hire world class lawyers to ensure that they have the best possible chance at the negotiating table. Kurdistan oil and gas industries have to strengthen the negotiation capacity to lay the foundation for getting more benefits from the contracts for maximizing the region revenues from the produced oil to contribute to Kurdistan region development.
B. Most of the agreements signed between MNR and international oil companies are production sharing contract (PSCs) by virtue of which the company will share $15 \%$ of the revenues and the interest in the blocks. Additionally, the company retains $55 \%$ of the revenues at the beginning of production till its costs are recovered. All these terms, make the oil companies the first beneficiaries in the contracts, leaving the government with fewer benefits compared to service contracts with oil companies. Hence, service contracts should paid more interest.

C. To avoid the big lack of transparency in the oil and gas activities as well as the significant mismanagement. The oil and gas law supposed to be implemented by 2008 (but it is still not fully implemented) should be fully implemented.

D. For better explorations, an effective inventory management is utmost essential for the best utilization of resources in remote area.

E. Safety must never be compromised. The oil and gas industry faces serious safety concerns as manifested by pipeline leaks and equipment failures. Oil companies must identify their most critical assets and prioritize maintenance efforts in order to maintain profitability

F. Oil and gas industry should focus on Process Safety Management (PSM) within the context of a health \& safety and environment (HSE) system. The goal is to manage all of the priorities safety, production efficiency cost effectiveness together and across the organization from the corporate headquarters to the various plant sites.

G. The growth in Kurdistan region of Iraq oil companies is essential to increase in power and possibility to acquire the necessary technological knowledge, what have to be very alarming for IOCs future concerns. R\&D and Innovation is a key to growth and prosperity.

H. Explore new industries based on using renewable resources as feed stocks for energy. Kurdistan Region of Iraq is rich in wild plants and natural resources which can form platforms for such novel industries.

I. The licensing contracts with IOCs need to be reviewed the review should be made public to avoid any suspicions of corruption and to establish contracts that are in line with the current economic situation. The contracts should take into account the possibility of a decline in oil prices and how the contracts can be amended.

\section{Conclusion}

Kurdistan region of Iraq sits on top of a liquid gold mine. The efforts and progress carried out in exploration and production combined with improving the infrastructure throughout a good management of oil and gas industry will result in maximizing the region revenues from the produced oil and gas. On another hand, using the revenues in right way will be a matter of prosperity and 
progress in particular when focuses on developing the oil industry. All that items form a strong base and efficient route to go towards allowing Kurdistan Region of Iraq to establish itself as a significant factor on the world stage.

\section{References}

1. http://ekurd.net/mismas/articles/misc2013/1/invest898.htm

2. https://www.oxfordenergy.org/w pcms/wp-content/ uploads/2016/02/Kurdish-Oil-and-Regional-Politics-WPM-63.pdf
3. http://investingroup.org/publications/kurdistan/overview/energy/

4. http://ekurd.net/work-kirkuk-gas-pipeline-turkey-2016-01-08

5. http://www.iraqoilreport.com/news/krg-to-tender-three-newrefineries-15378/

6. https://www.businessinsider.com.au/the-oil-potential-of-iraqikurdistan-2012-1

7. https://www.thebalance.com/how-are-oil-prices-determined-3305650
Creative Commons Attribution 4.0

International License

For possible submissions Click Here

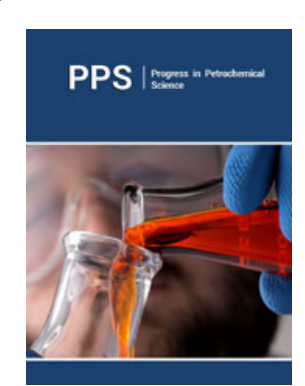

\section{Progress in Petrochemical Science}

Benefits of Publishing with us

- High-level peer review and editorial services

- Freely accessible online immediately upon publication

- Authors retain the copyright to their work

- Licensing it under a Creative Commons license

- Visibility through different online platforms 